\title{
Managing paediatric eosinophilic gastroenteropathies: a community experience
}

\author{
J Liem ${ }^{1,2 *}$, O Hakim ${ }^{3}$ A Zaher ${ }^{2}$ \\ From Canadian Society of Allergy and Clinical Immunology Annual Scientific Meeting 2009 \\ Halifax, Canada. 22-25 October 2009
}

\section{Introduction}

Awareness and diagnoses of eosinophilic gastroenteropathies have increased over the past decade. We report 3 cases of eosinophilic gastroenteropathies in children who were diagnosed by endoscopy, allergy tested by skin prick and patch testing, and managed with the use of avoidance/elemental diets.

\section{Case series}

KG, a 5 year old girl with daily abdominal pain, was diagnosed with eosinophilic esophagitis. Initial endoscopy revealed 20 eosinophils/hpf in the distal esophagus. Avoidance diet based on allergy testing was an ineffective treatment. An elemental diet of Neocate $(8$ weeks) resulted in resolution of symptoms and 0 eosinophils/hpf on repeat biopsy. She is currently on a gradual reintroduction diet.

$\mathrm{CD}$, an 11 year old boy with chronic diarrhea/constipation, abdominal pain and disruptive behaviour, was diagnosed with eosinophilic colitis. (60 eosinophils/hpf) An avoidance diet (8 weeks) based on allergy testing resulted in resolution of all abdominal symptoms and better behaviour. Repeat colonic biopsies revealed colonic eosinophils to be reduced back to normal limits. CD returned to normal diet, and symptoms have recurred.

TD, a 9 year old boy with daily stomach aches and vomiting, was diagnosed with eosinophilic esophagitis (20 eosinophils/hpf). An avoidance diet based on allergy testing resulted in resolution of symptoms. Repeat biopsy is pending.

\section{Conclusion}

Allergists play an important role in trying to identify the triggers for these conditions and implementing appropriate diets for management. The challenges in

'Windsor Allergy Asthma Education Centre, Canada managing these conditions in the community include i) no standard of care for management ii) availability of the 3 subspecialists (paediatric pathology, allergy and paediatric gastroenterology) with an interest/expertise in eosinophilic gastroenteropathies iii) health care resources (eg. availability of operating room time to perform repeat biopsies) iv) tolerability of avoidance/elemental diets.

\section{Author details}

${ }^{1}$ Windsor Allergy Asthma Education Centre, Canada . ${ }^{2}$ Department of Paediatrics, Southwestern Ontario Medical Education Network, Schulich School of Medicine and Dentistry, University of Western Ontario, Canada ${ }^{3}$ Department of Pathology and Laboratory Medicine, Windsor Regional Hospital, Canada.

Published: 12 May 2010

doi:10.1186/1710-1492-6-S1-P30

Cite this article as: Liem et al:: Managing paediatric eosinophilic gastroenteropathies: a community experience. Allergy, Asthma \& Clinical Immunology 2010 6(Suppl 1):P30.
Submit your next manuscript to BioMed Central and take full advantage of:

- Convenient online submission

- Thorough peer review

- No space constraints or color figure charges

- Immediate publication on acceptance

- Inclusion in PubMed, CAS, Scopus and Google Scholar

- Research which is freely available for redistribution

Submit your manuscript at www.biomedcentral.com/submit 